\title{
ШЛЯХИ ОПТИМІЗАЦЇ РОБОТИ СЕРЕДНЬОГО МЕДИЧНОГО ПЕРСОНАЛУ ТЕРАПЕВТИЧНОГО ВІДДІЛЕННЯ
}

\author{
Ю. І. Шинкарук
}

Вовчанський медичний коледж

У статті описано методи оптимізації роботи середнього медичного персоналу терапевтичного відділення, наведено соціометрію якості роботи та особового складу відділень за три роки. Подано узагальнені результати досліджень механізмів удосконалення роботи медичних установ.

\section{WAYS OF OPTIMIZATION OF PARAMEDICAL PERSONNEL WORK IN THE THERAPEUTIC DEPARTMENT}

\author{
Y. I. Shynkaruk
}

\section{Vovchanskyi Medical College}

The article describes the methods of optimization of paramedical personnel work in the therapeutic Department, the sociometry of the work and quality of personnel departments for three years. The generalized results of investigations of improvement mechanisms of medical institutions work are presented.

Вступ. Недосконала система стимулювання праці медичного персоналу, застарілі принципи її побудови та диференціації, мізерні розміри заробітку, неадекватні високій відповідальності та напруженості праці, призвели до падіння престижності праці лікаря, середнього медичного персоналу, руйнування зацікавленості працівників медичних установ у ефективній трудовій діяльності. Виникла необхідність у терміновому пошуку можливостей вдосконалення механізму стимулювання праці середнього медичного персоналу, підпорядкування його цілям подолання кризи здоров'я в Україні.

Здійснювані перетворення та зміни, які запроваджуються в системі охорони здоров'я, вимагають раціонального планування та організації всіх аспектів стаціонарної допомоги [1-8]. Для того, щоб досягти таких результатів, потрібно оптимізувати роботу медичного персоналу. Важливим $є$ раціональне використання часу для проведення огляду пацієнта, точне встановлення діагнозу, надання невідкладної допомоги. Також значимим $є$ інформатизація відділення для покращення роботи з пацієнтами та з ФАПами. Це також приведе до економії часу на зазначений етап роботи. Потрібно звернути увагу на сучасні техноло-

(c) Ю. І. Шинкарук, 2017 гії, які з'являються з кожним роком. Робота у царині цих технологій вимагає відповідної багатосторонньої підготовки всіх спеціалістів та відповідних нормативів роботи в сучасних економічних умовах.

Відсутні дослідження про організацію праці середніх медичних працівників терапевтичного відділення в нових соціально-економічних умовах. Багатоукладність фінансування стаціонарів вимагає формування інформаційної системи для ефективного управління роботою відділення, організації управління потоками пацієнтів та обліку допомоги, що надається пацієнтам.

Одним з основних завдань терапевтичного відділення на сучасному етапі $\epsilon$ інтеграція всіх засобів візуалізації, що вимагає відповідних організаційних рішень - об'єднання таких засобів в єдині підрозділи, як це організовано у всіх розвинених країнах $[9,10]$.

3 метою підвищення кваліфікації медичного персоналу доцільно брати участь у таких заходах: конференціях, симпозіумах, виступати з доповідями на наукових заходах різного спрямування, стажування за кордоном та запрошення колег. Обмін досвідом завжди ефективний.

Також важливим фактором підвищення якості роботи $є$ постійне удосконалення медичного приладдя 
для кращого надання медичної допомоги. Але у нашому регіоні, та і у всіх інших, як свідчать авторитетні джерела та соціологічні дослідження МОЗ України, з якими можна ознайомитись як на сайті, так і у фахових виданнях медичного спрямування, не вистачає коштів із бюджету, щоб вирішити таку проблему.

Все вищезазначене і зумовило актуальність проведення цього дослідження.

Мета роботи: вивчити вітчизняний досвід діяльності терапевтичних відділень на прикладі Вовчанської ЦРЛ, визначити перспективи розвитку та провести медико-соціальний та професійно-особистісний аналіз сестринського персоналу терапевтичного відділення зазначеної районної лікарні.

Для визначення об'єму і характеру навантаження середнього медичного персоналу терапевтичного відділення було проведено статистичний аналіз даних із карт хвороб пацієнтів, які лікувались протягом 2013-2015 pp.

Основна частина. Опрацювавши карти хвороб пацієнтів та медичну документацію, наявну у терапевтичному відділенні Вовчанської ЦРЛ, ми узагальнили та зібрали таку інформацію: план ліжко-днів виконаний на 96,7 \%, хворих госпіталізовують у відділення при наявності невідкладних показників. Збільшення кількості хворих та проведених ліжко-днів зумовлено зростанням захворюваності на серцево-судинну патологію, обстеженням призовників за направленням РВК та підвищенням контролю за видачою лікарняних листків у поліклініці. Кількість сільських жителів, пролікованих у стаціонарі, зменшилась до 33 \% у 2016 р. (табл. 1, рис. 1). Робота ліжко-днів у 2016 р. задовільна.

При вивченні складу середнього медичного персоналу терапевтичного відділення було встановлено, що більшу частину склали працівники віком 40-49 років (44,5 \%), 33,3 \% - від 20 до 29 років і 30-39 років $22,2 \%$. Більшість (55,5 \%) опитуваних не була у шлюбі, 22,2 \% розведені та 22,3 \% одружені.

Стаж роботи зі спеціальності склав: у медичних працівників, які працюють до 5 років - 11,2 \%, 5-10 років - 44,4 \%, більше 10 років - 44,4 \% (рис. 2). Середній медичний персонал відділення можна охарактеризувати так: 44,5 \% - працівники вищої категорії, 22,2 \% - II категорії, 33,3 \% - категорія відсутня (рис. 3).

Ряд питань анкети був спрямований на оцінку професійного рівня медичних працівників, ступеня їх інноваційної готовності, розвитку творчого потенціалу.

таблиця 1. Кількістьпролікованих у відділенні за 6 місяців 2015-2016 рр.

\begin{tabular}{|l|c|c|}
\hline & 2015 & 2016 \\
\hline План ліжко-днів & 4938 & 4938 \\
\hline Проведено ліжко-днів & 4819 & 4777 \\
\hline Виписано хворих & 526 & 463 \\
\hline У т. ч. сільських жителів & 201 & 177 \\
\hline Виконання плану ліжко-днів, \% & 97,5 & 96,7 \\
\hline
\end{tabular}

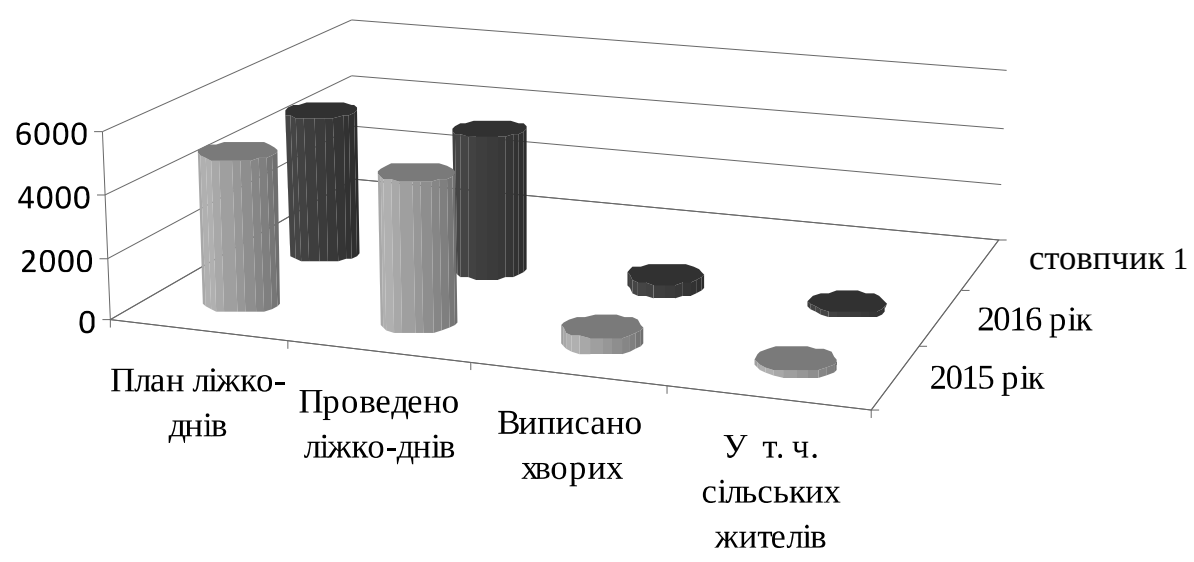

2015 pp.

2016 pp.

стовпчик 1

Puc. 1. Виконання плану ліжко-днів за 2015-2016 рр. 


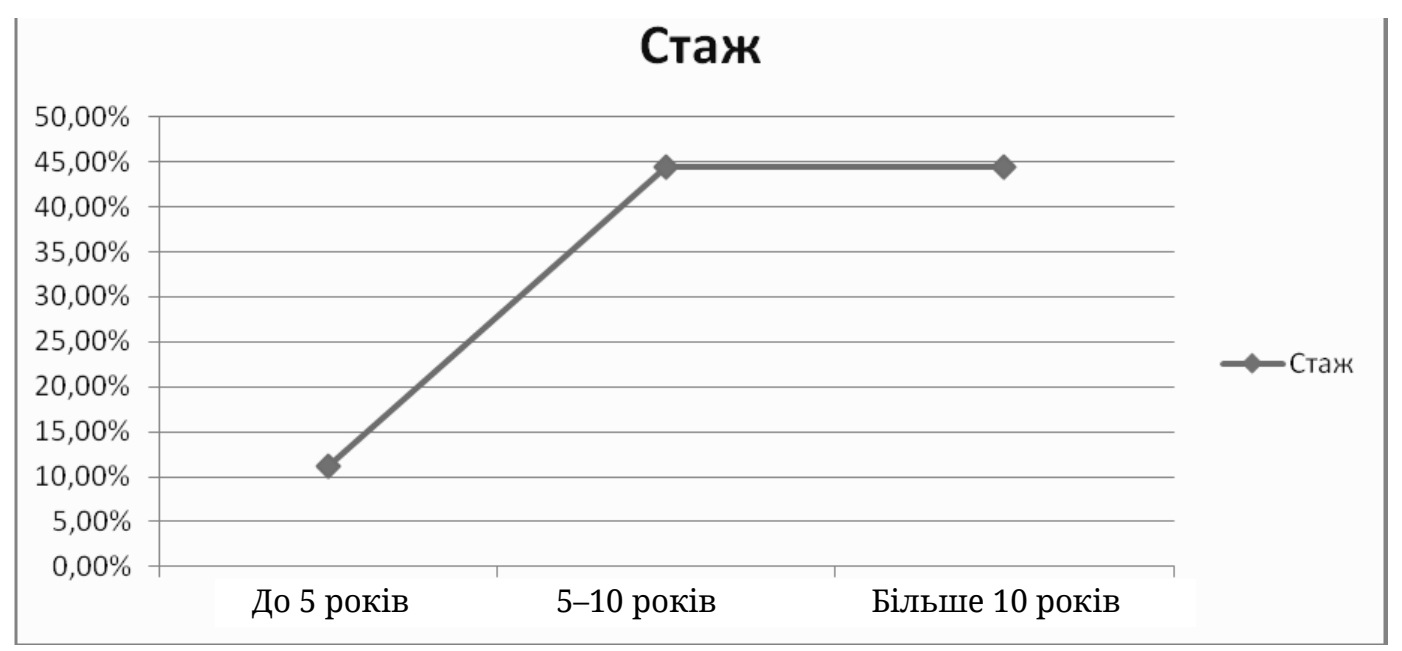

Puc. 2. Стаж роботи середнього медичного персоналу.

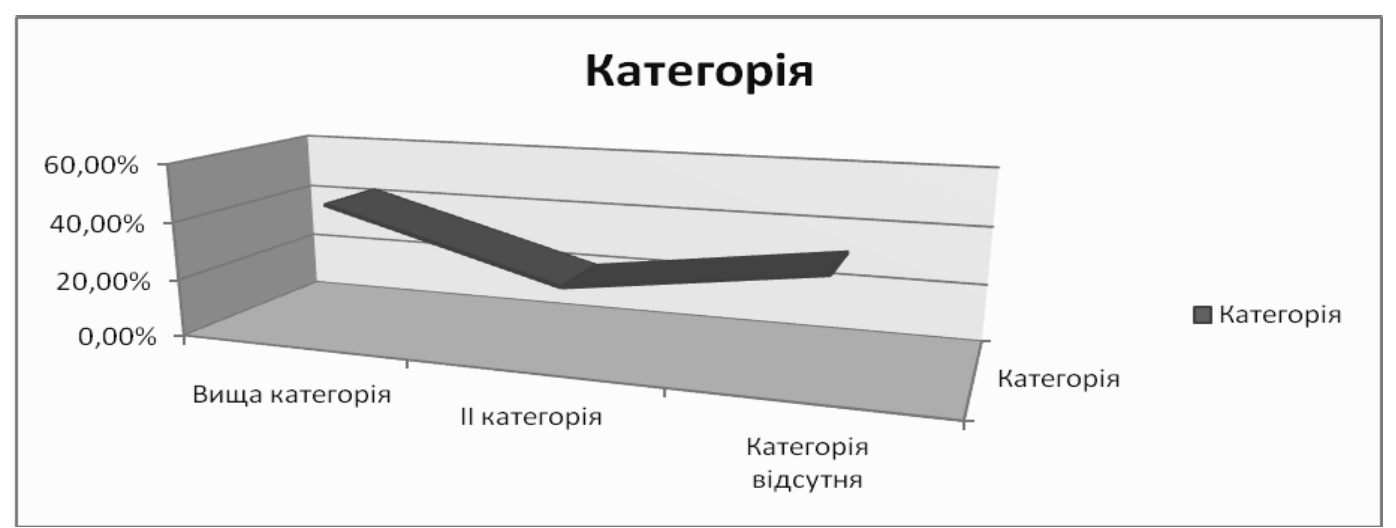

Puс. 3. Кваліфікаційний склад середнього медичного персоналу терапевтичного відділення.

Причини, через які працівники обрали цю професію, такі: 44,5 \% вказали, що працюють у лікарні через співчуття до людей, 22,2 \% - подобається ця професія і 33,3 \% утрималися від відповіді. Усі медичні працівники виявили рівень задоволення своїм вибором. Зазначено, що 88,8 \% опитуваних вважає, що лікар їм повністю довіряє і 22,2 \% іноді відчувають опіку з боку лікаря. 3 22,2 \% лікар іноді радиться при проведенні дослідження. Всі медичні працівники оцінили свій ступінь навантаження як досить значний. Великий відсоток, а саме 88,8 \% опитуваних вважають свою роботу небезпечною для здоров'я. Усі медичні працівники користуються засобами індивідуального захисту. Всі опитувані вважають, що їхня професія пов'язана з психічним напруженням.

Досліджуваним було поставлено запитання, чи відчувають вони нестачу знань і досвіду при виконанні ряду вузькоспеціалізованих методик. Значна частина опитуваних $(66,7$ \%) відповіла, що не має ніяких труднощів, і 33,3 \% відповіли, що такі труднощі виникають рідко.
Більша частина опитуваних 55,5\% вважає, що їхня робота творча, але і значна частина, а саме $44,5 \%$, так не вважає. Так, 22,2 \% опитуваних іноді не встигають зробити свої завдання через погано спланований робочий день; 88,8 \% так не вважають. 3 цих даних випливає, що труднощі виникають в працівників, у яких дуже малий стаж роботи (до 5 років). Ці працівники ще адаптовуються до умов праці. В цьому випадку потрібна допомога більш досвідчених медичних працівників.

Так, 88,9 \% вважають, що працівник сам вирішує, коли виконувати отримане завдання і лише $11,1 \%$ стверджують, що це не так. У питанні, чи завжди каралася ініціатива, 77,8 \% вказують, що не каралась, $11,1 \%$ - каралась завжди і 11,1\% - не завжди. Потрібно зазначити, що 66,7 \% стверджують доцільність підтримувати підлеглих у стані очікування підвищення зарплати і таким чином підвищиться якість надання медичної допомоги, але 33,3 \% так не вважають. 88,9\% опитуваних потребують на робочому місці комп'ютер і лише 11,1 \% його не потребують (таку відповідь 
отримано від персоналу, який працює більше 20 років у відділенні). Подібні результати було отримано у відповідь на запитання: «Чи потрібен вам помічник, якому зможете доручити частину своїх обов'язків?».

Вказано, що 77,8 \% СМП згодні з цим, що адміністратору необхідно бути в курсі особистого життя усіх своїх співробітників, 22,2\% так не вважають. І 66,6 \% стверджують, що при поганому виконанні своїх обов'язків повинно бути покарання, 33,4% вважають, що покарання тут недоцільне. Майже всі опитані вважають, що повинна бути сувора дисципліна. Дискусії у колективі, які призводять до конфліктів, є шкідливими $(66,6 \%)$, інші $(33,4 \%)$ так не вважають.

Творчою вважають свою роботу 66,7 \% співробітників і 33,3 \% негативної думки. Часовий режим виконання маніпуляції відповідає наказу МОЗ України. Таку відповідь дали 88,8 \% опитуваних і 11,2 \% так не вважають. Варто зазначити, що згодні із запитанням ті медичні працівники, які працюють у відділенні більше 5 років. Також 88,8 \% вважають, що можуть надихнути колектив на досягнення поставлених цілей на високому рівні та 11,2 \% не в змозі такого зробити. Варто зазначити, що багато медичних працівників хочуть змінити місце роботи через низьку заробітну плату ( 55,6 \%).

Із отриманих даних можна зазначити, що медичний персонал, який працює у терапевтичному відділенні, досить дружній. В основному намагаються уникати конфліктних ситуацій та допомагати один одному у вирішенні складних завдань. Робота медичних сестер терапевтичного відділення Вовчанської ЦРЛ повин-

\section{СПИСОК ЛІТЕРАТУРИ}

1. Бідний В. Г. Медичне страхування / В. Г. Бідний, Н. М. Орлова. - К., 2005. - 136 с.

2. Матеріали з медичної соціології / [уклад. І. 3. Держко та ін.] - Львів, 2008. - С. 16-21.

3. Медичне право України : збірник нормативноправових актів / [упоряд. і наук. ред. Н. Б. Болотіна]. К., 2001. - 412 c.

4. Москаленко В. Ф. Концепція розвитку охорони здоров'я - стратегія реформування галузі / В. Ф. Москаленко, В. М. Пономаренко // Лікарська справа. - 2001. № 1. - C. 3-9. на базуватися на основі системного планування, 3 повним отриманням усіх вимог до режиму праці відповідно до чинного законодавства.

Висновки. 1. У сучасних соціально-економічних умовах та наявності конкуренції між лікувально-профілактичними установами в управлінні діяльністю відділень необхідно використання маркетингових технологій і принципів менеджменту. Крім того, необхідно підвищувати ефективність роботи відділення. Позитивна сторона полягає в тому, що старша медична сестра управляє середнім медичним персоналом цього відділення, оскільки воно цілісне.

2. Координацію адміністративно-господарської діяльності необхідно покласти на старшу медичну сестру з вищою освітою, тобто сестру-менеджера, яка має великий досвід практичної діяльності у відділенні та знання, отримані з управління, економічних питань, маркетингу. Для оптимізації управління середнім медичним персоналом відділення ввести в структуру відділення штатну одиницю - «старша медична сестра-менеджер». Варто враховувати, що менеджером може бути тільки досвідчений співробітник, який володіє якостями лідера і має вищу освіту в галузі сестринської справи та менеджменту.

3. Підтверджено необхідність дотримуватись рівня теоретичної та практичної підготовки, який контролюється на базі тестування персоналу не рідше 1 разу на рік, із результатів систематичних занять щодо підвищення кваліфікації у відділенні, лікарні та на базі кваліфікаційних вимог згідно зі стандартами.

5. Нагорна А. М. Соціально-економічні детермінанти здоров'я населення України / А. М. Нагорна // Журнал Академії МНУ. - 2003. - Т. 9, № 2. - С. 325-346.

6. Соціальна медицина та організація охорони здоров'я : підручник / за ред. Ю. В. Вороненка. - Тернопіль. - 332 с.

7. Черносвитов Е. В. Социальная медицина / Е. В. Черносвитов. - М., 2003. - 624 с.

8. Філософські та соціально-екологічні проблеми медицини : навчальний посібник для студентів медичних вузів / за заг. ред. М. В. Кривоносова, А. П. Алексеєнко, І. С. Кратенка. - Харків, 2002. - С. 106-215. 